\title{
ICHTHYO AND HERPETOFAUNAL DIVERSITY OF KALAKKAD WILDLIFE SANCTUARY
}

\author{
P.T. Cherian, K. Rema Devi and M.S. Ravichandran \\ Southern Regional Station, Zoological Survey of India, 100 Santhome High Road, Chennai, Tamil Nadu 600028, India
}

\begin{abstract}
Relative to the area encompassing, Kalakkad Wildlife Sanctuary harbours a rich lower vertebrate fauna. This is more true in respect of fishes and amphibians about which more information is available. Based on recent studies, 84 species belonging to the lower vertebrate groups are found here which comprise four endemic to the Sanctuary, 32 to the Western Ghats mostly its southern ranges and 41 to India. The species composition and some of the factors contributing to the species richness of the Sanctuary are discussed.
\end{abstract}

\section{Introduction}

Consolidated information on the faunal diversity of most of our wildlife sanctuaries, national parks and biosphere reserves is rather non-existent. As part of an ongoing programme of the Zoological Survey of India (ZSI), attempts have been underway in recent years to survey and generate information on the faunal diversity of a few of the species-rich but little known ecosystems of our protected areas. Intensive faunistic surveys of various faunal groups were carried out by the scientists of Southern Regional Station, ZSI, Chennai from 1983 to 87 and in later years covering most of the areas of the Kalakkad Sanctuary. The study revealed a rich amphibian fauna, in this area followed by fishes and reptiles in that order.

Located on the eastern slopes of the southern Western Ghats, i.e. the area south of Palghat gap, in Tirunelveli District of Tamil Nadu, Kalakkad Wildlife Sanctuary covers an area of $223.76 \mathrm{~km}^{2}$.

The Sanctuary lies between $8^{\circ} 25^{\prime}$ and $8^{0} 35^{\prime} \mathrm{N}$ and $77^{\circ} 25^{\prime}$ and $77^{0} 35^{\prime} \mathrm{E}$. The hills are covered with dry deciduous forests on the lower slopes and evergreen sholas on the upper reaches, all traversed by rivulets, rivers and streams. Rivers of the area include Kodumudiar, Nambiar, Netterikal and Pachayar flowing eastwards and Kilmanimuthar traversing the western part.

\section{Ichthyofaunal diversity}

Earlier studies on the fishes of Kalakkad include the report of nine species by Silas (1953) with the description of a new genus
Horalabiosa and species $H$. joshuai and a subspecies Puntius arulius tambraparniei. Subsequent reports on the ichthyofauna of Kalakkad Wildlife Sanctuary are by Rema Devi (1992 a,b) who described a new hill stream fish Garra kalakadensis and later dealt with 19 species from the area (Table 1). Recently Rema Devi et al. (1997) listed 70 primary freshwater fishes from the Tambraparni River. The Tambraparni River system harbours three endemic species, of which H. joshuai and G. kalakadensis are confined to the hill streams in its higher reaches while the third species $P$. a. tambraparniei is found mostly in the lower reaches and in the plains. Of the 19 species collected from the hill streams 14 are found in peninsular India of which 12 have their range also in Sri Lanka and five in Pakistan, Nepal, Bangladesh and Myanmar. The ichthyofauna of Kalakkad is significant since two cyprinid species inhabiting torrential streams have evolved and thrive here at a general elevation of $1200 \mathrm{~m}$. A few specimens of G. kalakadensis were also encountered at an altitude of $190 \mathrm{~m}$. (Biometric studies of these two species viz. G. kalakadensis and H. joshuai revealed some morphometric variations in the populations from different drainages and altitudes). From the zoogeographical point of view a closer affinity is observed between the species of the southern Western Ghats and Sri Lanka since 63 per cent of the fish fauna found in this small Sanctuary alone have representatives in Sri Lanka. The nomenclature followed is after Menon (1993).

\section{Amphibian diversity}

Collection and study of over 1590 specimens from the area through three years from 1984 (Ravichandran, 1996, 1997) revealed that the sanctuary is home for a rich and diverse amphibian fauna. A comparison of the amphibian diversity (Ravichandran, 1996, 1997) and Zacherias and Bharadwaj (1996) represented by 35 species occurring in the Sanctuary far outnumber that hitherto recorded from any one of the three other better known conservation areas in the southern Western Ghats besides Silent Valley lying north of the Palghat gap. The nomenclature followed is after Inger and Dutta (1986).

Amphibians recorded from Kalakkad also comprise three Caecilian species collected in 1985 (Pillai \& Ravichandran, in press). 
Table 1. Ichthyofauna of Kalakkad Wildlife Sanctuary

\begin{tabular}{ll}
\hline \multicolumn{2}{c}{ Endemicity } \\
Western India \\
Ghats \\
\hline
\end{tabular}

Order : Cypriniformes

Family : Cyprinidae

1. Danio aequipinnatus (McClelland)

2. Esomus thermoicos (Valenciennes)

3. Rasbora daniconius (Hamilton)

4. Rasbora caverii (Jerdon)

5. Puntius bimaculatus (Bleeker)

6. Puntius chola (Hamilton)

7. Puntius dorsalis (Jerdon)

8. Puntius sarana subnasutus (Valenciennes)

9. Puntius punctatus (Day)

10. Horalabiosa joshuai silas*

11. Garra kalakadensis Rema Devi*

12. Garra mullya (Sykes)

Family : Homalopteridae

Subfamily: Homalopterinae

13. Bhavania australis (Jerdon)

Subfamily: Noemacheilinae

14. Noemacheilus triangularis Day

Family : Cobitidae

15. Lepidocephalus thermalis (Valenciennes)

Order : Siluriformes

Family : Bagridae

16. Mystus montanus (Jerdon)

17. Mystus vittatus (Bloch)

Order : Atheriniformes

Family : Cyprinodontidae

18. Aplocheilus lineatus (Valenciennes)

Order : Channiformes

Family : Channidae

19. Channa orientalis (Schneider)

(*Endemic to Kalakkad)

Table 2. Relative abundance of amphibians recorded from five conservation areas in the Western Ghats.

\begin{tabular}{llll}
\hline & Study area & No.of genera & No.of species \\
\hline 1. & Silent Valley & 11 & 19 \\
2. & Ponmudi & 11 & 25 \\
3. & Sabarigiri & 7 & 14 \\
4. & Periyar Wildlife Sanctuary & 6 & 16 \\
5. & Kalakkad Wildlife Sanctuary & 14 & 35 \\
\hline
\end{tabular}

The 35 species from Kalakkad dealt with here include 33 collected and studied by the authors since 1983 and one, Rhacophorus calcadensis Ahl recorded by Boulenger from the Sanctuary in 1882 (Inger and Dutta, 1986) under the preoccupied name R.beddomii but not sighted since. Hence its present status is uncertain. In addition, Melanobatrachus indicus Beddome was reported from the area by Karthikeyan (1997).

The amphibian fauna with 14 genera and 35 species occurring at Kalakkad is rich for a sanctuary of its size $\left(223.76 \mathrm{~km}^{2}\right)$ in India. The fauna represents a large component of endemic elements, since 21 species representing 60 per cent of the fauna found here are Indian endemics. Of these 19 species are exclusive to Western Ghats, of which 13 are confined only to the southern ranges of the Ghats. Besides, two species Rhacophorus calcadensis Ahl and Nyctibatrachus vasanthi Ravichandran found here are endemic to Kalakkad.

\section{Reptile diversity}

Reptiles are the least known of the lower vertebrate groups of the Sanctuary. Murthy (1990) reported 26 species from here. His studies were supplemented by the works of Krishnan (1985) who observed three more species viz. King Cobra, Indian Python and Flying Lizard in the Sanctuary. During the present studies, apart from confirming the occurrence of these three species, one more species, Indian Cobra was also found distributed here. The nomenclature followed is after Murthy (1990).

The nature of the terrain and various other contributing factors as also the relative abundance of other vertebrate groups in the area all point to the possibility of a large component of reptiles here. Hence the 30 species so far recorded from the sanctuary may at best constitute only a fraction of the total species diversity of reptiles found here.

Though none of the reptiles so far known is endemic to the sanctuary, 40 per cent of the species found here are endemic to India which include eight species confined to the Western Ghats. Besides, 15 species comprising 50 per cent of the fauna found here are common to Sri Lanka, showing closer affinity of the fauna of the two areas.

The proximity of the Sanctuary to the equator where the largest number of species are found according to the principle of latitudinal diversity gradient (Wilson, 1992) is partly because of the steady shrinking of the ranges of individual species. The closer one comes to the equator, the impacts of abundant solar energy and stable climate the terrain experiences, the telescoping of a wide range of altitudinal variations from a few metres above sea level to $1775 \mathrm{~m}$. into a small area of over $200 \mathrm{~km}^{2}$, the occurrence of rain shadow areas on the eastern slopes and heavily rain fed ones on the western higher ranges, all leading to the development of an admixture of deciduous and 
Table 3. Amphibian fauna of Kalakkad Wildlife Sanctuary

\begin{tabular}{llc}
\hline Name of species & $\begin{array}{c}\text { Endemic to } \\
\text { W.Ghats India } \\
\text { W. Ghats }\end{array}$ & \\
\hline
\end{tabular}

\section{Order : Anura}

Family: Bufonidae

1. Bufo melanostictus Schneider

2. B. microtympanum Boulenger

3. Melanobatrachus indicus Beddome

4. Microhyla ornata (Duméril\& Bibron)

5. M. rubra (Jerdon)

6. Ramanella montana(Jerdon)

\section{Family: Ranidae}

7. Euphlyctis cyanophlyctis Schnieder

8. Hoplobatrachus tigerinus Daudin

9. Micrixalus fuscus (Boulenger)

10. M. opisthorhodus (Günther)

11. M. silvaticus (Boulenger)

12. Nanobatrachus beddomii (Boulenger)

13. Nyctibatrachus aliciae Inger, Shaffer, Koshy \& Bakde

14. N. deccanensis Dubois

15. N. major Boulenger

16. N. vasanthi Ravichandran *

17. Rana aurantiaca Boulenger

18. R. beddomii (Günther)

19. R. brachytarsus (Günther)

20. R. curtipes Jerdon

21. R. keralensis Dubois

22. R. limnocharis Boie

23. R. malabarica Tschudi

24. R. temporalis Günther

25. Tomopterna breviceps Schneider

Family: Rhacophoridae

26. Philautus beddomii (Günther)

27. P. femoralis (Günther)

28. P. nasutus (Günther)

29. P. pulcherrimus (Ahl)

30. P. variabilis (Günther)

31. Polypedates maculatus (Gray)

32. Rhacophorus calcadensis Ahl*

Order : Gymnophiona

Family: Ichthyophidae Taylor

33. Ichthyophis longicephalus Pillai

34. Uraeotyphlus melabaricus (Beddome)

35. U. oxyurus (Duméril \& Bibron)

$\begin{array}{llll} & & + & + \\ & + & + & + \\ & + & + & + \\ & + & + & + \\ & + & + & + \\ & + & + & + \\ & & + & + \\ & & + & + \\ & + & + \\ & & + \\ & & & + \\ & & & +\end{array}$

( ${ }^{\star}$ Endemic to Kalakkad)

semievergreen forests, sholas and rolling tall grass clearings have contributed to the richness and diversity of the fauna of the Sanctuary.

The richness and diversity of the fauna, the degree of endemism observed among the faunal components, the presence of 'refugial pockets' in the area which serve as home for many of the species which are rare or face various levels of threat to their existence in even other parts of the Western Ghats, qualifies the Kalakkad Sanctuary to be considered one of the "hottest of the hot spots" 
Table 4. Reptilian fauna of Kalakkad Willdlife Sanctuary

\begin{tabular}{ll}
\hline \multicolumn{2}{c}{ Endemism } \\
Western India \\
Ghats
\end{tabular}

Class : Reptilia

Order : Testudines

Family : Emydidae

1. Melanochelys trijuga trijuga(Schweigger)

Family: Testudinidae

2. Geochelone elegans (Schoepff)

Order : Squamata

Suborder : Sauria

Family : Gekkonidae

3. Cnemaspis ornata (Beddome)

4. Dravidogecko anamallensis (Günther)

5. Hemidactylus leschenaulti Duméril \& Bibron

Family : Agamidae

6. Calotes calotes (Linn)

7. Calotes elliotti Günther

8. Calotes grandisquamis Günther

9. Calotes versicolor (Daudin)

10. Draco dussumieri Duméril \& Bibron

11. Psammophilus dorsalis (Gray)

12. Sitana ponticeriana Cuvier

Family: Chamaeleonidae

13. Chameleo zeylanicus Laurenti

Family: Scincide

14. Mabuya beddomii (Jerdon)

15. Mabuya macularia (Blyth)

Suborder : Serpentes

Family : Boidae

16. Python molurus Linn.

\section{Family : Colubridae}

17. Ahaetulla dispar (Günther)

18. Ahaetulla nasuta (Lacepede)

19. Ahaetulla pulverulenta (Duméril \& Bibron)

20. Amphiesma beddomei (Günther)

21. Elaphe helena (Daudin)

22. Liopeltis calamaria (Günther)

23. Oligodon travancoricus Beddome

24. Xenochrophis piscator (Schneider)

Family : Elapidae

25. Calliophis melanurus (Shaw)

26. Naja naja Linn.

27. Ophiophagus hannah Canton

28. Hypnale hypnale (Merrem)

29. Trimeresurus macrolepis Beddome

30. Trimeresurus malabaricus (Jerdon) of the world today.

\section{Acknowledgements}

We are thankful to the Director, Zoological Survey of India, Calcutta, for encouragement.

\section{References}

Inger, R.F. and S.K. Dutta (1986). An overview of the amphibian fauna of India. J. Bombay nat. Hist. Soc., 83 (Suppl.): 135-146.

Inger, R.F., H.B. Shaffer., M. Koshy and R. Bakde (1984). A report on a collection of amphibians and reptiles from the Ponmudi, Kerala, South India. J. Bombay nat. Hist. Soc., 81: 406-427.

Karthikeyan, V. (1997). Rediscovery of the black Microhylid frog, Melanobatrachus indicus (Beddome, 1878). J. Bombay nat. Hist. Soc., 94(1): 170

Krishnan, M. (1985). Report: National Wildlife Action Plan. Kalakad Sanctuary, Tiruneveli Dist., Tamil Nadu, 5 pp.

Murthy, T.S.N. (1990). Reptiles of Kalakkad Sanctuary, India. The Snake, 22, 44-59.

Menon, A.G.K. (1993). Check-list. Fresh water fishes of India, 457 pp. Rec. Zool. Surv. India., Occasional paper (In Press).

Pillai, R.S. and M.S. Ravichandran. Gymnophiona (Amphibia) of India, A Taxonomic Study. Rec. Zool. Surv. India, Occasional paper (In Press)

Ravichandran, M.S. (1996). Amphibia of the Kalakkad Wildlife Sanctuary, Tamil Nadu, India. Cobra, 23: 15-31.

Ravichandran, M.S. (1997). A new frog of the genus Nyctibatrachus (Anura: Ranidae) from southern India. Hamadryad, 22(1): 9-12.

Rema Devi, K. (1992(a). Garra kalakadensis, a new Cyprinid fish from Kalakad Wildlife Sanctuary, Tiruneveli District, Tamil Nadu. Rec. Zool. Surv. India, 91(2): 239-245.

Rema Devi, K. (1992(b). Fishes of Kalakkad Wildlife Sanctuary, Tirunelveli District, Tamil Nadu, India, with a redescription of Horalabiosa joshuai Silas. Rec. Zool. Surv. India, 92 (1-4): 193-209.

Rema Devi, K., T.J. Indra., M.B. Raghunathan., M. Mary Bai and M.S. Ravichandran (1997). Ichthyofauna of the Tambraparni River System Tamil Nadu. Zoos' Print, 12(7): 1-2.

Silas, E.G. (1953). New fishes of the Western Ghats with notes on Puntius arulius (Jerdon). Rec. Indian Mus., 51: 27-38, pl. 1.

Wilson, E.O. (1992). Diversity of life. W.W. Northon and Co. New York, $412 \mathrm{pp}$.

+. Zacherias, V.J. and S.K. Bharadwaj (1996). The Indian Forester, 12(3): 247-249. 